\title{
REPORT OF THE WORKSHOP, "PALEOENVIRONMENTS OF THE EASTERN MEDITERRANEAN,” 19 MAY 1991
}

The Workshop was a unique mélange of interdisciplinary research results, presented by key researchers of the Middle East. The presentations are now being expanded for publication of "Late Quaternary Chronology and Paleoclimates of the Eastern Mediterranean” in 1993.

Henry Schwarcz spoke of electron spin resonance (ESR), uranium (U)-series, thermoluminescence (TL) and optically stimulated luminescence (OSL) dating of such prehistoric sites as Qafzeh, Kebara, Skhul and Tabun. William Farrand followed with a discussion of geologic stratigraphy and radiometric dates from these sites, and raised the issue of discordance between ESR/TL dates and paleoenvironmental settings, cultural associations and human physical types. Fred Wendorf presented dating results from lacustrine deposits of the Egyptian Sahara through U-series, ESR, TL, amino acid racemization (AAR) of ostrich eggshell and radiocarbon $\left({ }^{14} \mathrm{C}\right)$ analyses. Attempts to correlate time scales using these techniques, as well as oxygen-isotope $\left({ }^{18} \mathrm{O}\right)$ records of deep-sea sediments, have been inconclusive.

Rupert Housley reviewed Oxford accelerator mass spectrometric (AMS) measurements on archaeological samples from the Middle East. Juris Zarins focused on archaeological and geological records of the Arabian peninsula from the Upper Paleolithic and Early Holocene through ${ }^{14} \mathrm{C}$, climatological and deep-sea-core data. Mebus Geyh presented previously unpublished groundwater and speleothem isotope data that characterize eastern Mediterranean hydrology for the past 30,000 years. Michel Fontugne made ${ }^{14} \mathrm{C}$ accelerator mass spectrometric (AMS) measurements on organicrich layers (sapropel) in deep eastern Mediterranean Sea sediments and determined ${ }^{18} \mathrm{O}$ values of the Nile River. His results attest to a major pluvial period during the Holocene over the entire eastern Mediterranean. Ann El-Moslimany presented palynological and floral evidence corroborating increased summer precipitation in the Middle East during the Early Holocene.

Glenn Goodfriend reported results of ${ }^{18} \mathrm{O}$ analyses of shell carbonate from Holocene land snails of the northern Negev, which indicated that precipitation changes occurred about 1000 years later than in findings reported above. Research by Amos Frumkin and Israel Carmi on salt caves of Mount Sedom traced the climatic history of the Dead Sea during the Holocene, and results correlated well with sedimentological, archaeological and historical records.

Hendrik Bruins proposed a system-analysis approach to studying cause-and-effect linkages between human and environmental histories. Using Abu Hureyra as a model representing the transition from hunting and gathering to early Holocene farming, Andrew Moore discussed the implications of 40 AMS results on faunal bones and cereal seeds from the site. Alan Simmons ended the session by exploring the ${ }^{14} \mathrm{C}$ chronology of Akrotiri Aetokremnos, Cyprus, the oldest site on the island, and its contribution to a better understanding of the "reservoir effect" in the Mediterranean area.

The Workshop brought together scholars to discuss impacts of paleoclimatic events on cultural history. Although the prehistory of this area remains controversial, problems regarding interpretations of such climatic events can be settled only through open exchange of data and ideas.

Renee S. Kra

Department of Geosciences, The University of Arizona, Tucson, Arizona 85721 USA

Ofer Bar-Yosef

Department of Anthropology, Harvard University, Cambridge, Massachusetts 02138 USA 